\title{
Fusarium spp. Causing Dry Rot of Seed Potato Tubers in Michigan and Their Sensitivity to Fungicides
}

E. Gachango, Department of Plant Pathology, L. E. Hanson, Department of Plant Pathology and United States Department of Agriculture-Agricultural Research Service, and A. Rojas, J. J. Hao, and W. W. Kirk, Department of Plant Pathology, Michigan State University, East Lansing 48824

\begin{abstract}
Gachango, E., Hanson, L. E., Rojas, A., Hao, J. J., and Kirk, W. W. 2012. Fusarium spp. causing dry rot of seed potato tubers in Michigan and their sensitivity to fungicides. Plant Dis. 96:1767-1774.

A survey of seed potato tubers in Michigan seed production storage facilities was carried out during 2009 and 2010. Fusarium spp. associated with tuber dry rot symptoms were identified to species and tested for sensitivity to difenoconazole, fludioxonil, and thiabendazole. Symptomatic tubers $(n=370)$ were collected from a total of 51 seed lots, from which 228 isolates of Fusarium were recovered and identified to 11 species. Fusarium oxysporum was the most commonly isolated species (30.3\%), followed by F. equiseti (19.3\%). F. sambucinum and $F$. avenaceum were third most prevalent (each at $13.6 \%$ ). Less prevalent species (each at 4 to $10 \%$ ) included F. cerealis, F. solani, and $F$. acuminatum; and species present at $\leq 3 \%$ included $F$. sporotrichioides, F. torulosum, F. tricinctum, and F. graminearum. Representative

isolates of all species were pathogenic when inoculated onto seed tubers ('Dark Red Norland'). Isolates of $F$. sambucinum were the most virulent. All 228 isolates of Fusarium were sensitive to difenoconazole (effective fungicide concentration that caused $50 \%$ inhibition of mycelial growth $\left[\mathrm{EC}_{50}\right]<5 \mathrm{mg} /$ liter $)$. Insensitivity to fludioxonil $\left(\mathrm{EC}_{50}>\right.$ $100 \mathrm{mg} /$ liter) was detected only for $F$. sambucinum and $F$. oxysporum isolates at 8.9 and $20.4 \%$, respectively. All isolates were sensitive to thiabendazole $\left(\mathrm{EC}_{50}<5 \mathrm{mg} / \mathrm{liter}\right)$, except for those of $F$. sambucinum $\left(\mathrm{EC}_{50}>100 \mathrm{mg} / \mathrm{liter}\right)$. Therefore, knowledge of what Fusarium spp. are present in seed potato storage facilities in Michigan may be important if using fludioxonil or thiabendazole for seed piece treatment but not when using difenoconazole.
\end{abstract}

Fusarium dry rot of potato (Solanum tuberosum L.) can be a devastating postharvest disease worldwide and is caused by several species of Fusarium $(5,42)$. Dry rot affects both tubers in storage and seed tuber pieces in the field $(7,48)$. Losses associated with dry rot have been estimated to range from 6 to $25 \%$, and occasionally losses as great as $60 \%$ have been reported during long-term storage $(12,42)$.

Infection of potato tubers by dry rot pathogens occurs through wounds inflicted during harvesting, grading, cutting, and handling of tubers $(39,42)$. Thirteen species of Fusarium have been implicated in fungal dry rots of potato worldwide $(8,20)$; of which eight species have been reported in the northern United States (19). The most prevalent species infecting potato are $F$. sambucinum Fuckel; (syn. F. sulphureum Schltdl., tel. Gibberella pulicaris), F. solani var. caeruleum (Lib. ex Sacc.) C. Booth (syn. F. caeruleum, tel: Nectria haematocca), and F. oxysporum Schltdl. (19). Other species reported in the northern United States include $F$. avenaceum (Fr.) Sacc., F. culmorum (W.G. Sm.) Sacc., F. acuminatum Ellis \& Everh., F. equiseti (Corda) Sacc., and F. crookwellense L.W. Burgess, P.E. Nelson \& Toussoun (F. cerealis) $(19,34)$. Most of these species were also recovered in a study in the Pacific region of the United States, with $F$. sambucinum being the most prevalent (34). Recently, $F$. graminearum was reported to be the most prevalent Fusarium sp. causing potato dry rot in North Dakota $(2,13)$.

In Michigan, potato seed tubers are produced in the Upper and Lower Peninsulas (29). The limited seed tuber generation program in Michigan was adopted in 2002 and utilizes the tissue culture system (47). With tissue culture, plants are produced under aseptic conditions, tested for various bacterial and viral diseases, and

Corresponding author: W. W. Kirk, E-mail: kirkw@msu.edu

Accepted for publication 23 June 2012

http://dx.doi.org/10.1094/PDIS-11-11-0932-RE

(C) 2012 The American Phytopathological Society transplanted into greenhouses to produce the nuclear class of seed or what is commonly known as mini-tubers. This involves meristem, tissue culture seed stock development, after which mini-tubers or tissue culture plantlets are planted into a field or fields as the initial source of certified seed potato lots. The seed lots are then multiplied and increased to reach a sufficient quantity for commercial use for up to six generations (Field Year 1 to 6 Class Seed), after which the seed lot is no longer eligible for recertification. The seed lots entered for Michigan certification are tested in the winter in south Florida. On passing this test, the seed lots are evaluated by Michigan State Department of Agriculture seed inspectors prior to shipping seed tubers from the Michigan seed farms. The seed lots that pass this stage achieve "blue tag" certification (U.S. Standards for Seed Potato Grades Regulation number 628) from the Michigan Seed Potato Association (MPSA; Gaylord, MI) and the Michigan Department of Agriculture (MPSA Director E. Dorman, Plant Pathology Laboratory, East Lansing) (29).

Seed and commercial potato growers receive seed as whole tubers to grow for recertification as seed or for commercial production. The tubers are cut into pieces and treated with a seed treatment such as fludioxonil or thiabendazole prior to planting (48). Cutting seed tubers potentially exposes the seed pieces to contamination or infection by pathogens such as Fusarium spp., which may lead to dry rot development in the field or in storage once tubers are wounded during harvesting. For most $(>50 \%)$ potato seed lots in Michigan, some level of dry rot has been reported (22). F. sambucinum was the predominant species affecting seed potato tubers selected from a single storage in Michigan in 2006, causing seed piece decay after planting (25) and rotting sprouts of the progeny tubers (49). Since the report of Lacy and Hammerschmidt in 1993 (25), there has been no systematic assessment of Fusarium spp. responsible for dry rot on seed potato tuber stocks in Michigan. There are also no commercially grown potato cultivars resistant to dry rot in North America, although the level of resistance varies among some cultivars and breeding lines (26). Understanding the Fusarium spp. composition in outbreaks of potato dry rot is of importance in designing both chemical and cultural management (crop rotation) schemes for potato dry rot because different crops 
may harbor different Fusarium spp. that can vary in pathogenicity and sensitivity toward fungicides.

Fusarium dry rot on seed potato can be controlled in two phases during the potato growth cycle: (i) control of seed piece decay prior to planting, which is primarily achieved by seed treatment; and (ii) postharvest control of dry rot on both stored commercial tubers and seed tubers (33). Fludioxonil (Maxim Seed Potato Protectant; Syngenta Crop Protection), a phenylpyrrole, is among the few fungicides registered for potato seed treatment against Fusarium dry rot in the United States (48). Studies have shown that fludioxonil is able to reduce seed piece decay as well as the incidence of diseased sprouts (48) that develop into infected plants. Recently, fludioxonil-resistant strains of Fusarium spp. were reported in Canada and the United States, including strains of $F$. sambucinum, $F$. oxysporum, and $F$. coeruleum $(16,38)$. However, sensitivity to fludioxonil in other Fusarium spp. that cause potato seed piece decay is not known.

Postharvest management of potato dry rot has been achieved primarily by reducing tuber bruising, providing conditions for rapid wound healing (41), and applying thiabendazole, a benzimidazole fungicide (TBZ or Mertect 340F, Syngenta Crop Protection), as tubers are placed into storage $(20,34)$. Isolates of $F$. sambucinum resistant to TBZ were found first in Europe (20) and subsequently in the United States $(10,11)$. Fungicide resistance has reduced the efficacy of TBZ in controlling $F$. sambucinum (34) but may be useful where TBZ-sensitive isolates still occur (10). Resistance to TBZ has also been reported in other Fusarium spp. isolated from dry rot potato tubers, including $F$. oxysporum, $F$. solani, $F$. culmorum (19,34), F. avenaceum, F. equiseti, F. sporotrichioides (34), and F. acuminatum (19).

To counteract the reduced effectiveness of TBZ (34) and, potentially, of fludioxonil associated with resistant strains of pathogen, additional registrations of efficacious postharvest fungicides are needed and some fungicides have been tested, including difenoconazole (Inspire; Seed Potato Protectant; Syngenta Crop Protection), a sterol biosynthesis inhibitor (1). The objectives of this study were to (i) characterize the Fusarium spp. responsible for dry rot of seed potato tubers produced in Michigan and (ii) determine the sensitivity to fludioxonil and TBZ as well as establish baseline sensitivity levels for difenoconazole in Fusarium populations recovered from Michigan potato seed lots.

\section{Materials and Methods}

Fusarium isolation and species identification. Dry-rotsymptomatic seed tubers were collected from April to May 2009 and 2010. A total of 370 tubers was collected for processing. The potato tubers were sourced from 18 storage facilities located in the Upper and Lower Peninsulas of Michigan, and represented the

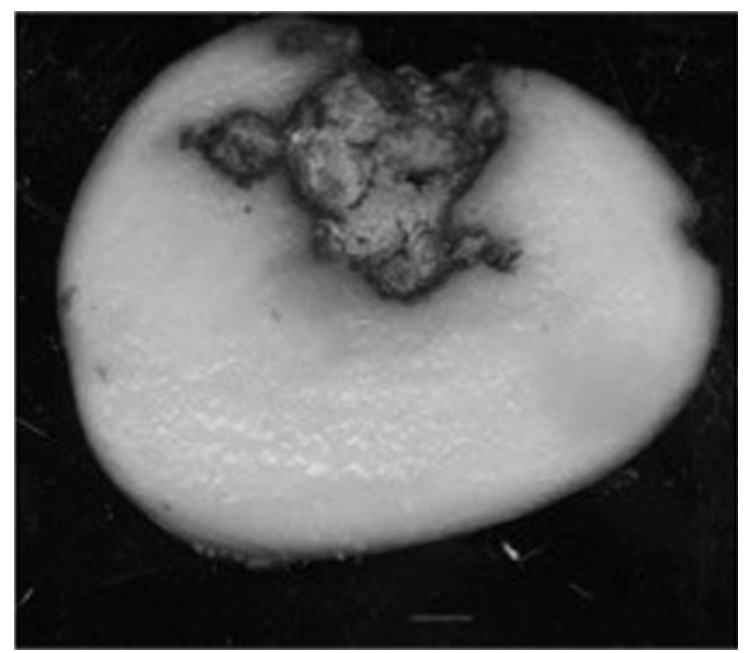

Fig. 1. Potato tuber infected with Fusarium dry rot and cut open through the dry rot lesion. entire seed potato production area in Michigan, which comprised 950 ha. On average, seed lots of about 70 public and 60 proprietary potato cultivars are produced in Michigan annually and the fields vary in size from 0.2 to 50 ha (29). The tuber samples collected in this study represented potato harvested from 51 seed lots (total) and comprised eight public cultivars ('Dark Red Norland', 'Russet Burbank', 'Katahdin', 'Atlantic', 'Eva', 'Goldrush-CF9-5', 'Snowden', and 'CFT-6') as well as five proprietary cultivars. The seed tubers all originated in Michigan and were from seed lots that had achieved "blue tag" certification from the MPSA and the Michigan Department of Agriculture. The class year was not specified on the samples. The average number of tubers sampled was 10/seed lot in 2008 whereas, in 2009 , the number of tubers in a sample varied from 5 to 10 tubers/seed lot.

All the symptomatic sampled tubers had shallow or sunken and wrinkled necrotic areas that were discolored light to dark brown, indicating the presence of dry rot symptoms. Small pieces $(0.5 \mathrm{~cm}$ in diameter, six pieces/tuber) were cut from the margins of the tuber flesh showing dry rot symptoms using a sterile scalpel, and then each piece of tuber was surface disinfested in $0.5 \%$ sodium hypochlorite for $10 \mathrm{~s}$, rinsed twice in sterile distilled water, and blotted dry with sterile filter paper. The tissue pieces were plated on half-strength potato dextrose agar (PDA; Difco Laboratories) amended with streptomycin at $0.5 \mathrm{~g} /$ liter. The petri dishes were incubated at $23^{\circ} \mathrm{C}$ for 5 to 7 days in alternating $12 \mathrm{~h}$ of light and 12 $\mathrm{h}$ of darkness.

Cultures resembling Fusarium spp. were transferred onto plates of water agar. To generate pure cultures, hyphal tip transfers from each colony to carnation leaf agar and half-strength PDA were done from the margin of actively growing isolates using a sterile probe. The pure cultures were identified to species based on conidial morphology, production of chlamydospores, growth characteristics, and colony pigmentation as described by Leslie et al. (27). To confirm species identity, lyophilized mycelium from each pure culture grown on PDA for 7 days was used for DNA extraction as described by Goodwin et al. (18), followed by amplification and sequencing of the translation elongation factor $1 \alpha$ gene region (17). The Fusarium-ID (17) and the National Center for Biotechnology Information (GenBank) databases were used to obtain the closest match in nucleotide sequences (lowest $e$ value, maximum coverage, and highest identity) to the same gene regions of previously sequenced isolates of Fusarium.

Pathogenicity test. All 228 Fusarium isolates were tested for pathogenicity on 3-month-old, asymptomatic potato tubers of Dark Red Norland. Dark Red Norland was used as a representative of seed potato cultivars produced in Michigan because no cultivar is resistant to dry rot (39). The tubers were each surface disinfested for $10 \mathrm{~min}$ in $0.5 \%$ sodium hypochlorite, and rinsed twice in sterile water. Three replicate tubers/isolate were each injected with $20 \mu \mathrm{l}$ of a conidial suspension (approximately $10^{6}$ conidia/ml as determined by a hemacytometer) of the appropriate Fusarium isolate grown on PDA for 7 days; three control tubers were each injected with $20 \mu \mathrm{l}$ of sterile distilled water. The tubers (three tubers/temperature/isolate) were incubated in the dark for 30 days at 4 and $10^{\circ} \mathrm{C}$. The two storage temperatures were used to compare virulence of all the Fusarium isolates recovered. After 30 days of incubation, tubers were cut in half through the point of inoculation and evaluated for the development of symptoms typical of potato dry rot: dry, necrotic areas discolored light to dark chocolate brown on the tuber surface (Fig. 1). Isolates that caused symptoms on all three tubers at both temperatures were considered pathogenic. The fungi were reisolated (as described above) from all the symptomatic potato tubers and compared morphologically with the original isolate used in each inoculation. Isolation from the control tubers was also done to demonstrate that the seed tubers did not have natural infection by Fusarium spp.

Virulence test. To assess the virulence level of the Fusarium isolates, images of the symptomatic areas on the inoculated tuber surfaces were generated from a method adapted from Niemira et al. (31), described below. The freshly cut tuber sections were 
placed on a piece of glass ( $30 \mathrm{~cm}$ by $40 \mathrm{~cm}$ by $2 \mathrm{~mm}$ ), with the cut tuber surface facing down. A ruler was placed underneath the glass and used for measurements during image analysis. The glass and ruler were transferred to a flatbed scanner (HP Scan-Jet 4c; Hewlett Packard Co.) for image processing. Scanner control software (DeskScan II version 2.4; Hewlett Packard Co.) generated an image of the cut tuber surfaces against a black background (30). The image files created were first loaded into Adobe Photoshop CS3 (version 10.01, 2007; Adobe Systems Incorporated), from which the lesions were selected on each image and "painted" white using the "fill" tool. The images were then loaded into SigmaScan Pro 5 (version 1987-1999; SPSS Inc.) to determine the area of the lesion as described by O'Neal et al. (36), with modifications as follows. The lesion length and width (in millimeters) were measured to calculate the dimension and area (in square millimeters) of the lesions, and calibrated to convert image pixels to a unit of measurement using the ruler within the image. The measurement "fill' was then adjusted to a threshold so that the lesion was a lighter color than the rest of the tuber surface. The area of the lesion was then measured according to the SigmaScan manufacturer's protocol.

Fungicide sensitivity assays. All the Fusarium isolates identified were screened for fungicide sensitivity using two screening methods described below. Two $F$. sambucinum isolates, thiabendazole-resistant (R-09271-Desjardins YG-1 U7200A) and thiabendazole-sensitive (R-00738, R. C. Cetas), were used as standard isolates for comparison with the 228 isolates in the thiabendazolesensitivity assay. A conidial suspension (approximately $10^{6}$ conidia/ml) of each isolate was prepared as described above. Three fungicides were used as formulated products in aqueous suspensions: fludioxonil (0.5\% a.i., formulated as Maxim; Syngenta Crop Protection), thiabendazole (42.3\% a.i., formulated as TBZ or Mertect; Syngenta Crop Protection), and difenoconazole (23.2\% a.i., formulated as Inspire; Syngenta Crop Protection). A stock concentration of $10,000 \mathrm{mg} / \mathrm{liter}$ was prepared for each fungicide by dissolving the fungicide in sterile distilled water. Aliquots were made each day of the experiment for the spiral gradient dilution method. Serial dilutions from 0 to $100 \mathrm{mg} /$ liter were also prepared for the serial dilution plate (SDP) method.

Spiral gradient dilution method. The fungicide spiral gradient dilution (SGD) method was used to estimate the effective fungicide concentration that caused 50\% inhibition of mycelial growth $\left(\mathrm{EC}_{50}\right)$ values as described by Förster et al. (14). PDA $(50 \mathrm{ml})$ was poured into each $15-\mathrm{cm}$-diameter petri dish at least $24 \mathrm{~h}$ before each fungicide suspension was applied. A 50- $\mu$ l fungicide suspension from each of the stock suspensions was applied with a spiral plater (SGE; Spiral Biotech, Inc.) using the exponential deposition mode. The plates were incubated for $3 \mathrm{~h}$ to allow the fungicides to diffuse into the agar medium and form a gradient of concentration along the radius of the plate. Each plate was placed on the template provided by SGE. The template was a transparent polyester sheet marked as a circle with internal concentric radial lines at 2-mm intervals from 20 to $64 \mathrm{~mm}$ with 15 marked polygons ( 6 by $45 \mathrm{~mm}$ running from the outside to the center of the circle at equally spaced positions from 0 to $315^{\circ}$, cutting across the radial lines for positioning the samples). Droplets of the appropriate conidial suspension $(10 \mu \mathrm{l}$ each) were spread across the radial lines in predetermined plate positions using a sterile plastic pestle. Three replicate plates per isolate were used for each fungicide and the experiment was conducted twice. Control treatments consisted of PDA plates without fungicides added, to which the appropriate conidial suspension was applied with a sterile plastic pestle. The plates were incubated at $25^{\circ} \mathrm{C}$ for 3 days. Radial growth of the fungal isolate on each replicate plate was measured and the values averaged. The radial distance between the center of the plate and the location on the plate where growth was inhibited 50\% compared with the control plate was used in the SGE software to calculate the $\mathrm{EC}_{50}$ values of each Fusarium isolate.

SDP method. Plates of PDA were amended with each of the fungicides listed above at concentrations of $0,0.1,1.0,10.0$, or
$100.0 \mathrm{mg} /$ liter. Colonized agar plugs $(5 \mathrm{~mm}$ in diameter) were cut for each isolate from the margin of colonies and placed on the amended agar medium with the colonized-side of the agar plug in direct contact with the agar, and incubated for 5 days in the dark at $25^{\circ} \mathrm{C}$. Colony diameter was measured with a caliper after 5 days and the diameter of the inoculation plug subtracted. Fungal growth was expressed as percent inhibition of the fungal growth compared with colony diameter on the control plates without fungicide. Three replicate plates per treatment were used, and the experiment was conducted twice. $\mathrm{EC}_{50}$ values for each isolate were calculated by regression analysis of percent growth inhibition versus the log fungicide concentration using Sigmaplot (version 9.01; Systat Software, Inc.). Fludioxonil insensitivity was defined as lack of growth inhibition of an isolate on PDA containing fludioxonil at 100 $\mathrm{mg} / \mathrm{liter}$ (38). Insensitivity for difenoconazole and TBZ were defined as $\mathrm{EC}_{50} \geq 5 \mathrm{mg} /$ liter based on previous thresholds set for these fungicides $(19,34)$. Each isolate was classified as sensitive or resistant to each of the three fungicides based on these thresholds. Each experiment was arranged in a completely randomized design and data analysis was completed as described below.

Statistical analysis. All data analyses were conducted with JMP (version 8.0; SAS Inc.), except for the regression analyses. Data for the repeated experiments were first tested for homogeneity of variances using Bartlett's test of homogeneity. The data were also tested for significance of the main effects and interactions. Because variances were homogeneous for each experiment and no significant differences were measured between the repeats of any of the experiments, the data were combined and analyzed statistically using analysis of variance. Means separation was performed using Tukey's honestly significantly difference test.

\section{Results}

Fusarium isolation and identification. Over the 2-year survey, 228 Fusarium isolates were recovered and identified to 11 species (Table 1). The proportion of the recovered isolates identified per species remained markedly consistent over the 2-year period despite a smaller sample size in 2010 (110 potato tubers) compared with 2009 (260 potato tubers), with the exception that $F$. sporotrichioides and $F$. graminearum each were isolated in only 1 of the 2 years. $F$. oxysporum was the most commonly isolated species, comprising $>25 \%$ of the isolates both years (Table 1). F. equiseti was the second most commonly isolated species in both years (Table 1). F. sambucinum and $F$. avenaceum were third in prevalence, each comprising $13.6 \%$ of the isolates averaged over both years (Table 1). Less prevalent Fusarium spp. (4 to 10\% incidence) included $F$. cerealis, F. solani, and $F$. acuminatum. Other Fusarium spp. (3\% each) included F. sporotrichioides, F. torulosum, F.

Table 1. Relative frequencies of Fusarium spp. isolated from symptomatic seed potato tubers sampled during 2009 and 2010 from seed lots produced in Michigan

\begin{tabular}{lccc}
\hline & \multicolumn{3}{c}{ Relative frequency $(\%)$ of isolated } \\
species & \\
\cline { 2 - 4 } Fusarium spp. & $\mathbf{2 0 0 9}$ & $\mathbf{2 0 1 0}$ & Total \\
\hline Fusarium oxysporum & 28.8 & 25.9 & 30.3 \\
F. equiseti & 23.0 & 19.0 & 19.3 \\
F. sambucinum & 14.9 & 13.3 & 13.6 \\
F. avenaceum & 11.1 & 17.1 & 13.6 \\
F. solani & 9.5 & 5.2 & 7.5 \\
F. cerealis & 6.3 & 5.1 & 6.1 \\
F. acuminatum & 4.1 & 6.9 & 4.4 \\
F. torulosum & 1.4 & 3.1 & 2.2 \\
F. tricinctum & 0.9 & 3.1 & 1.8 \\
F. sporotrichioides & 0.9 & 0.0 & 0.9 \\
F. graminearum & 0.0 & 1.7 & 0.4 \\
Total number of isolates & 169 & 59 & 228 \\
Total number of tubers sampled & 260 & 110 & 370 \\
\hline
\end{tabular}

${ }^{\mathrm{z}}$ Relative frequency $=$ percentage of isolates of a given species relative to the total number of isolates recovered in 2009 and 2010 (169 and 59 isolates), respectively. 
tricinctum, and $F$. graminearum. The majority of isolates from dry rot lesions were identified as Fusarium spp. (61.6\%). The bulk of the remaining fungal isolates were Alternaria spp. that were not identified to species. Of the $38.4 \%$ of the isolates not identified to species, 5\% were Fusarium-like but not Fusarium, because they produced white to cream-colored, dense mycelia, with no spore formation.

Pathogenicity. All the Fusarium isolates recovered were pathogenic to potato tubers of Dark Red Norland at both 4 and $10^{\circ} \mathrm{C}$ (Fig. 2). The inoculated tubers developed typical potato dry rot symptoms of a brown and dry decay regardless of which isolate of Fusarium was inoculated. No dry rot symptoms were observed on the noninoculated control potato tubers.

Virulence. No significant differences in virulence were measured between the two executions of the experiments at each of the temperatures (Table 2); therefore, data were combined for subsequent analyses. The average lesion diameters on inoculated tubers were 52.99 and $55.65 \mathrm{~mm}^{2}$ from experiments 1 and 2, respectively, at $10^{\circ} \mathrm{C}$; and 43.79 and $43.67 \mathrm{~mm}^{2}$, respectively, at $4^{\circ} \mathrm{C}$ (Table 2).

Significant differences in virulence among isolate of the 11 Fusarium spp. were evident (Table 3). Overall, F. sambucinum was the most virulent species, causing significantly $(P=0.0001)$ larger lesions compared with that of the other species at both 4 and $10^{\circ} \mathrm{C}$ storage temperatures. The rest of the species did not differ significantly with respect to diseased area on inoculated tubers at either temperature. There was a significant $(P=0.0001)$ difference in virulence within isolates of $F$. sambucinum but not within isolates of the rest of the species (data not shown). The same fungal species was reisolated from the diseased area of the inoculated tubers, thus completing Koch's postulates for each species. The lesion area observed on inoculated tubers incubated at $10^{\circ} \mathrm{C}$ was not significantly $(P=0.6774)$ different from that of tubers stored at $4^{\circ} \mathrm{C}$.

Fungicide sensitivity of dry rot Fusarium spp. No significant differences in fungicide sensitivity were measured between the two executions of the experiments for any of the fungicides tested or the two methods used for testing sensitivity (SGD and SDP analyses; Tables 2 and 4); therefore, data across repeat experiments were combined for subsequent analyses within each method of testing for fungicide sensitivity. The SGD method of testing fungicide sensitivity gave slightly lower $\mathrm{EC}_{50}$ values compared with the SDP method for the 228 isolates of Fusarium tested; however, the two methods were not significantly different $(P=0.7752)$ and the $\mathrm{EC}_{50}$ values were within similar ranges for both methods with each of the three fungicides tested (Table 5).
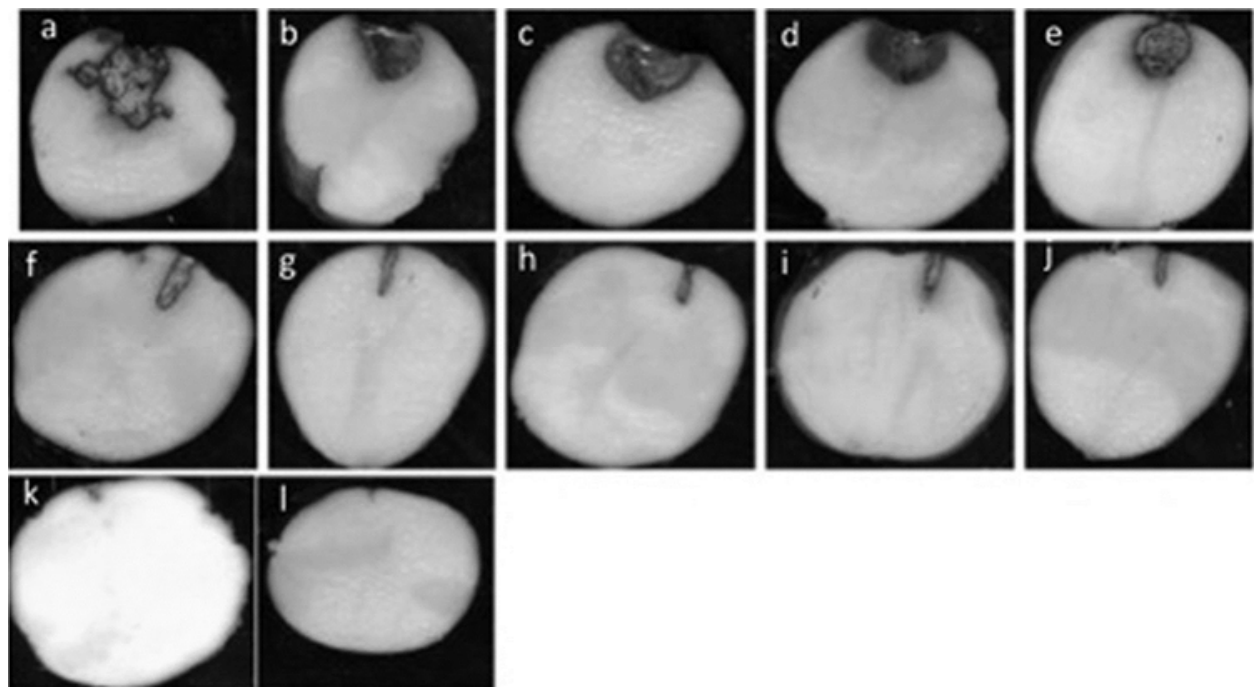

Fig. 2. Pathogenicity of Fusarium isolates obtained from Michigan potato seed pieces with dry rot symptoms and inoculated onto seed potato tubers ('Dark Red Norland'). Isolates of the following species were tested: a, Fusarium sambucinum; b, F. avenaceum; c, F. tricinctum; d, F. acuminatum; e, F. cerealis; $\mathbf{f}, F$. sporotrichioides; $\mathbf{g}, F$. solani; h, F. equiseti; i, F. oxysporum; j, F. torulosum; k, F. graminearum; and I, noninoculated control tubers.

Table 2. Results ( $P$ values) for the main effects in the analyses of variance for virulence and effective fungicide concentration that caused $50 \%$ inhibition of mycelial growth $\left(\mathrm{EC}_{50}\right)$ values for each of three fungicides calculated by the spiral dilution gradient (SGD) and serial dilution plate (SDP) methods for sensitivity of 11 species of Fusarium isolates, obtained from dry rot-symptomatic tubers in Michigan potato seed crops for a repeated experiment (experiments 1 and 2)

\begin{tabular}{|c|c|c|c|c|c|c|c|c|c|}
\hline \multirow[b]{2}{*}{ Dependent variables } & \multirow[b]{2}{*}{ Temperature, fungicide ${ }^{t}$} & \multirow[b]{2}{*}{$F$ ratio $^{u}$} & \multirow[b]{2}{*}{ Prob $<F^{\mathrm{u}}$} & \multicolumn{3}{|c|}{ Lesion area $\left(\mathbf{m m}^{2}\right)$} & \multicolumn{3}{|c|}{$\mathbf{E C}_{50}(\mathrm{mg} / \text { liter })^{\mathrm{s}}$} \\
\hline & & & & $\operatorname{Exp} 1$ & $\operatorname{Exp} 2^{v}$ & HSD $^{w}$ & $\operatorname{Exp} 1$ & $\operatorname{Exp} 2^{v}$ & HSD $^{\mathrm{w}}$ \\
\hline \multirow[t]{2}{*}{ Virulence $^{\mathrm{x}}$} & $10^{\circ} \mathrm{C}$ & 0.2059 & 0.6501 & 52.99 & 55.65 & 11.502 & $\ldots$ & $\ldots$ & $\ldots$ \\
\hline & $4^{\circ} \mathrm{C}$ & 0.0007 & 0.9791 & 43.79 & 43.67 & 9.722 & & & \\
\hline \multirow[t]{3}{*}{ SGD $^{y}$} & Difenoconazole & 1.6551 & 0.1989 & $\ldots$ & $\ldots$ & $\ldots$ & 1.68 & 1.77 & 0.133 \\
\hline & Fludioxonil & 0.0000 & 1.0000 & $\ldots$ & $\ldots$ & $\ldots$ & 1.99 & 1.99 & 0.141 \\
\hline & Thiabendazole & 1.9641 & 0.1619 & $\ldots$ & $\ldots$ & $\ldots$ & 2.74 & 2.89 & 0.201 \\
\hline \multirow[t]{3}{*}{$\mathrm{SDP}^{\mathrm{z}}$} & Difenoconazole & 2.7876 & 0.0957 & $\ldots$ & $\ldots$ & $\ldots$ & 1.88 & 1.70 & 0.213 \\
\hline & Fludioxonil & 1.3436 & 0.2474 & $\ldots$ & $\ldots$ & $\ldots$ & 2.77 & 2.93 & 0.263 \\
\hline & Thiabendazole & 0.0319 & 0.8583 & $\ldots$ & $\ldots$ & $\ldots$ & 3.73 & 3.71 & 0.225 \\
\hline
\end{tabular}

${ }^{\mathrm{s}} \mathrm{EC}_{50}$ was calculated by regression analysis of percent growth inhibition versus the log fungicide concentration using Sigmaplot.

${ }^{\mathrm{t}}$ Storage temperature or fungicide tested.

" Model mean square divided by the error mean square and Prob $<F$ lists the $P$ value for the test. Values of 0.05 or less were considered evidence that there was at least one significant effect in the model.

${ }^{\vee} \operatorname{Exp}=$ experiment; Exp 2 is a repeat of Exp 1.

${ }^{\mathrm{w}} \mathrm{HSD}=$ Tukey's Honestly significant difference of the comparison between repeats of the experiments for each measured variable.

${ }^{x}$ Virulence was estimated as the mean area of the lesion after inoculation of potato tubers (cv. Dark Red Norland).

y SGD method $(14,21)$.

${ }^{\text {z }}$ SPD method $(14,21)$. 
Difenoconazole. All the Fusarium isolates were sensitive to difenoconazole using both screening methods based on the criterion of an $\mathrm{EC}_{50}$ value $<5 \mathrm{mg} /$ liter (Table 5). F. equiseti had a significantly greater $\mathrm{EC}_{50}$ compared with that of $F$. graminearum, $F$. sporotrichiodes, $F$. torulosum, $F$. acuminatum, $F$. avenaceum, and $F$. sambucinum based on the SGD method but not the SPD method.

Fludioxonil. In both experiments, sensitive and insensitive isolates of $F$. sambucinum and $F$. oxysporum were identified. The insensitive isolates for each species had $\mathrm{EC}_{50}$ values $>100 \mathrm{mg} / \mathrm{liter}$ and represented $8.9 \%$ of the F. sambucinum isolates and $20.4 \%$ of the $F$. oxysporum isolates, respectively (Fig. 3). In all, 6 isolates of $F$. sambucinum, 14 isolates of $F$. oxysporum, and all isolates of the other nine species were sensitive to fludioxonil, with $\mathrm{EC}_{50}$ values $<5 \mathrm{mg} /$ liter (Table 5). F. sambucinum isolates had a significantly greater $\mathrm{EC}_{50}$ compared with isolates of $F$. avenaceum and $F$. cerealis when the SGD method was used (Table 5).

Thiabendazole. Insensitivity to thiabendazole was observed for some of the Fusarium isolates tested based on growth on PDA containing TBZ at $5 \mathrm{mg} / \mathrm{liter}$. All isolates of $F$. sambucinum and the known TBZ-insensitive $F$. sambucinum isolate (R-09271) were insensitive to $\mathrm{TBZ}$, with $\mathrm{EC}_{50}$ values $>100 \mathrm{mg} / \mathrm{liter}$. However, isolates from the rest of the species and the TBZ-sensitive F. sambucinum isolate (R-00738) were sensitive to $\mathrm{TBZ}$, with $\mathrm{EC}_{50}$ values $<5$ $\mathrm{mg} /$ liter (Table 5). Fusarium spp. isolates with $\mathrm{EC}_{50}$ values from
2.9 to $2.2,2.6$ to 1.6 , and 2.3 to $1.0 \mathrm{mg} / \mathrm{liter}$ and 4.4 to $3.0,3.6$ to $2.3,3.6$ to 1.8 , and 3.1 to $1.6 \mathrm{mg} /$ liter were not significantly different when the SGD and SPD methods, respectively, were used to determine different degrees of sensitivity to TBZ (Table 5).

\section{Discussion}

F. sambucinum has been the predominant causal agent of potato tuber dry rot in storage and seed piece decay in the northern United States, including Michigan $(25,42)$. However, in this 2-year survey, 11 Fusarium spp. were recovered from diseased seed tubers produced in Michigan. The most frequently isolated species was $F$. oxysporum, which concurs with similar reports from other areas of the United States $(19,34)$. All of the isolates of $F$. oxysporum were pathogenic to potato tubers of Dark Red Norland. The prevalence of $F$. oxysporum may pose a challenge to potato growers because the isolates of $F$. oxysporum have also been found to cause wilting of potato plants $(28,42)$. It is not known whether the isolates that cause dry rot can also cause wilt; therefore, this warrants further investigation (46).

$F$. equiseti was the second most commonly isolated species. Leslie et al. (27) indicated that $F$. equiseti can be divided into biological species using molecular techniques, thus making it a species complex. This species complex has not been reported previously from potato tubers in Michigan. However, Hanson et al. (19)

Table 3. Virulence of Fusarium isolates on potato tubers ('Dark Red Norland') based on the area (in square millimeters) of the dry rot lesion on cut tubers after 30 days of incubation of the inoculated tubers at 4 and $10^{\circ} \mathrm{C}^{\mathrm{z}}$

\begin{tabular}{|c|c|c|c|c|c|}
\hline \multirow[b]{3}{*}{ Fusarium spp. } & \multirow[b]{3}{*}{ Number of isolates } & \multicolumn{4}{|c|}{ Incubation temperature } \\
\hline & & \multicolumn{2}{|c|}{$4^{\circ} \mathrm{C}$} & \multicolumn{2}{|c|}{$10^{\circ} \mathrm{C}$} \\
\hline & & Range & Mean & Range & Mean \\
\hline Fusarium sambucinum & 31 & $12.9-589.9$ & $234.2 \mathrm{a}$ & $6.9-1186.8$ & $250.6 \mathrm{a}$ \\
\hline F. tricinctum & 4 & $9.7-17.5$ & $14.3 \mathrm{~b}$ & $27.6-85.2$ & $47.3 \mathrm{~b}$ \\
\hline F. sporotrichioides & 2 & $8.9-20.9$ & $14.5 \mathrm{~b}$ & $17.6-46.7$ & $33.4 \mathrm{~b}$ \\
\hline F. cerealis & 17 & 13.0-20.9 & $17.2 \mathrm{~b}$ & $1.3-351.4$ & $31.9 \mathrm{~b}$ \\
\hline F. torulosum & 5 & $12.0-12.7$ & $15.4 \mathrm{~b}$ & $5.4-64.8$ & $30.2 \mathrm{~b}$ \\
\hline F. equiseti & 44 & $8.1-31.1$ & $17.6 \mathrm{~b}$ & $8.7-52.9$ & $29.6 \mathrm{~b}$ \\
\hline F. solani & 13 & $9.5-26.1$ & $17.4 \mathrm{~b}$ & $7.5-64.8$ & $29.0 \mathrm{~b}$ \\
\hline F. oxysporum & 69 & $9.9-30.3$ & $17.4 \mathrm{~b}$ & $8.2-89.4$ & $28.6 \mathrm{~b}$ \\
\hline F. avenaceum & 31 & $8.3-35.0$ & $17.2 \mathrm{~b}$ & $3.0-194.8$ & $19.8 \mathrm{~b}$ \\
\hline F. acuminatum & 11 & $6.4-32.5$ & $14.6 \mathrm{~b}$ & $4.2-29.5$ & $11.3 \mathrm{~b}$ \\
\hline F. graminearum & 1 & $1.5-1.6$ & $1.6 \mathrm{~b}$ & $2.2-2.4$ & $2.3 \mathrm{~b}$ \\
\hline Noninoculated control & $\ldots$ & 0.0 & $0.0 \mathrm{~b}$ & 0.0 & $0.0 \mathrm{~b}$ \\
\hline HSD & $\ldots$ & $\ldots$ & 144.3 & $\ldots$ & 157.3 \\
\hline Prob $F(P<0.05)$ & $\ldots$ & $\ldots$ & $<0.0001$ & $\ldots$ & $<0.0001$ \\
\hline
\end{tabular}

${ }^{\mathrm{z}}$ Mean area of the lesion for all isolates within a species (mean of three replicates per isolate) and the experiment was conducted twice. Data were pooled, because there were no significant differences between the two experiments at either temperature (Table 2). Numbers followed by the same letter within a column are not significantly different at $P=0.05$ by Tukey's honestly significantly difference (HSD) test.

Table 4. Results ( $P$ values) of the analyses of variance (ANOVAs) for the main effects of Fusarium spp. and isolates of each species, and interactions between these two factors on effective fungicide concentration that caused $50 \%$ inhibition of mycelial growth $\left(\mathrm{EC}_{50}\right)$ values when the isolates were tested for sensitivity to difenoconazole, fludioxonil, and thiabendazole using the spiral gradient dilution (SGD) and serial dilution plate (SDP) methods ${ }^{y}$

\begin{tabular}{|c|c|c|c|c|c|}
\hline \multirow[b]{3}{*}{ Fungicide } & \multirow[b]{3}{*}{ ANOVA factors } & \multicolumn{4}{|c|}{$P$ values ${ }^{\mathrm{z}}$} \\
\hline & & \multicolumn{2}{|c|}{ SGD experiments } & \multicolumn{2}{|c|}{ SDP experiments } \\
\hline & & 1 & 2 & 1 & 2 \\
\hline \multirow{3}{*}{ Difenoconazole } & Species & $<0.0001$ & $<0.0001$ & $<0.0001$ & $<0.0001$ \\
\hline & Isolate & 0.0722 & 0.7222 & 0.9991 & 0.9992 \\
\hline & Species $\times$ isolate & 0.8939 & 0.8939 & 0.5636 & 0.5665 \\
\hline \multirow[t]{3}{*}{ Fludioxonil } & Species & $<0.0001$ & $<0.0001$ & $<0.0001$ & $<0.0001$ \\
\hline & Isolate & 0.9928 & 0.9929 & 0.4677 & 0.4677 \\
\hline & Species $\times$ isolate & 0.1897 & 0.1897 & 0.8829 & 0.8829 \\
\hline \multirow[t]{3}{*}{ Thiabendazole } & Species & 0.6992 & 0.7024 & $<0.0001$ & $<0.0001$ \\
\hline & Isolate & 1.0000 & 1.0000 & 0.9994 & 0.5994 \\
\hline & Species $\times$ isolate & 0.0041 & 0.0041 & 0.0481 & 0.0481 \\
\hline
\end{tabular}

${ }^{y} \mathrm{EC}_{50}$ was calculated by regression analysis of percent growth inhibition versus the log fungicide concentration using Sigmaplot. The experiment was conducted twice.

${ }^{\mathrm{z}}$ Probability value (values of 0.05 or less were considered evidence that there was at least one significant effect in the model). For SGD and SDP, three replicates of each isolate were tested independently with each fungicide and the experiment conducted twice (14,21). Experiment 2 was a repeat of experiment 1. 
reported the $F$. equiseti species complex associated with potato tubers in the northern United States, although at a low frequency $(0.7 \%)$ in comparison with the incidence observed in this Michigan study $(19.3 \%) . F$. equiseti has also been reported in other areas of the world $(44,45)$ and is a potential human pathogen capable of producing mycotoxins (27). A high prevalence in potato tubers may be of concern for human food safety because $F$. equiseti is also allergenic to humans.

$F$. sambucinum and $F$. avenaceum were third most prevalent in this Michigan potato seed tuber survey. F. sambucinum has been reported as a commonly isolated Fusarium sp. from dry-rotsymptomatic tubers in the northeastern United States (19) and the Columbia Basin of Oregon and Washington (34) but is less common than F. oxysporum $(19,34)$. Although $F$. sambucinum was not the most prevalent species in this study, isolates of this species were the most virulent, causing significantly larger lesions than isolates of the other 10 species evaluated at both 4 and $10^{\circ} \mathrm{C}$ tuber incubation temperatures. These results are in agreement with those of Ocamb et al. (34), who reported that $F$. sambucinum isolates caused relatively larger areas of tuber decay compared with isolates of $F$. oxysporum and $F$. solani. Several authors have reported that $F$. sambucinum is the major dry rot pathogen of potato tubers in the northern United States $(10,42)$. However, this study indicated there were at least four other Fusarium spp. which caused the development of tuber lesions $>30 \mathrm{~mm}^{2}$, although three of these four species were found at a low frequency $(<4 \%)$ over the 2 years of this Michigan study. The four species included F. tricinctum, $F$. sporotrichioides, F. torulosum, and F. cerealis but, compared with the relatively small areas of tuber decay these isolates caused compared with isolates of $F$. sambucinum, they may not be major potato pathogens.

A preliminary report was published in 2011 on the presence of F. torulosum as a potato pathogen in the United States (15). However, F. torulosum was only separated from F. sambucinum in 1995 (32) and, therefore, may have been present in potato tubers previously but not recognized. Although $F$. avenaceum is most commonly reported as a cereal pathogen (27), the prevalence of this species in this study was the same as that of $F$. sambucinum. In the northern U.S. potato regions, $F$. avenaceum has been less commonly reported from potato tubers than $F$. oxysporum, $F$. solani, and $F$. sambucinum (19) whereas, in the United Kingdom, $F$. avenaceum has been recovered at greater frequencies $(8,37)$, and the species has been reported in other northern European countries such as Finland (43). The prevalence of $F$. avenaceum isolates in Michigan potato seed lots may have an implication for crop rotations because potato is usually rotated with cereal crops. Fusarium spp. being both seed- and soilborne indicates that the primary sources of inoculum may be infected seed tubers or infested soil (42). The presence of inoculum in the soil or in seed tubers could lead to infection of the tubers through wounds inflicted during harvesting and dry rot development during storage. All Michigan isolates of $F$. avenaceum tested in this study were pathogenic to seed tubers of Dark Red Norland at both 4 and $10^{\circ} \mathrm{C}$, although the virulence of the isolates was low at both temperatures. In contrast, Aprasad et al. (4) found that isolates of $F$. avenaceum were slightly more virulent at 5 than at $10^{\circ} \mathrm{C}$. In Scotland, isolates of $F$. avenaceum caused more dry rot compared with isolates of $F$. solani var. coeruleum $(7,8)$.

Only one isolate of $F$. graminearum was isolated from Michigan seed lots in this study, and caused small dry rot lesions when

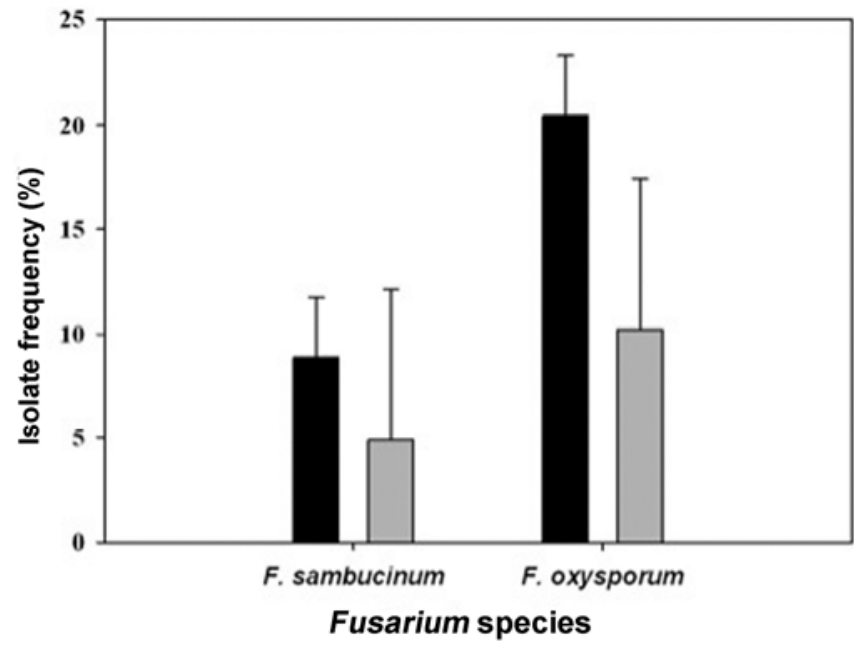

Fig. 3. Frequency of Fusarium sambucinum and F. oxysporum isolates sensitive (gray bars) and insensitive (black bars) to fludioxonil, obtained from Michigan potato seed tubers with dry rot symptoms. The frequency was calculated relative to the total number of $F$. sambucinum and $F$. oxysporum isolates tested for fludioxonil sensitivity ( $n=14$ and 6 , respectively). Each data point represents the mean and standard deviation of the mean.

Table 5. Effective fungicide concentration that caused $50 \%$ inhibition of mycelial growth $\left(\mathrm{EC}_{50}\right)$ of Fusarium spp. causing potato dry rot as determined by the spiral gradient dilution (SGD) and serial dilution plate (SDP) methods ${ }^{\mathrm{v}}$

\begin{tabular}{|c|c|c|c|c|c|c|c|}
\hline \multirow[b]{3}{*}{ Fusarium spp. } & \multirow[b]{3}{*}{$N^{\mathrm{x}}$} & \multicolumn{6}{|c|}{$\mathrm{EC}_{50}$ for inhibition of mycelial growth (mg/liter) ${ }^{\mathrm{w}}$} \\
\hline & & \multicolumn{2}{|c|}{ Difenoconazole } & \multicolumn{2}{|c|}{ Fludioxonil } & \multicolumn{2}{|c|}{ Thiabendazole } \\
\hline & & SGD & SDP & SGD & SDP & SGD & SDP \\
\hline Fusarium oxysporum & 68 & $1.7 \mathrm{abc}$ & $1.6 \mathrm{a}$ & $2.3 \mathrm{ab}$ & $4.3 \mathrm{a}^{\mathrm{y}}$ & $2.6 \mathrm{ab}$ & $2.6 \mathrm{bcd}$ \\
\hline F. equiseti & 44 & $2.3 \mathrm{a}$ & $2.4 \mathrm{a}$ & $1.6 \mathrm{ab}$ & $3.5 \mathrm{a}$ & $2.2 \mathrm{abc}$ & $1.8 \mathrm{~cd}$ \\
\hline F. sambucinum & 31 & $1.4 \mathrm{bc}$ & $1.3 \mathrm{a}$ & $2.7 \mathrm{a}^{\mathrm{y}}$ & $3.3 \mathrm{a}^{\mathrm{y}}$ & $\ldots$ & $\ldots$ \\
\hline F. avenaceum & 31 & $0.8 \mathrm{c}$ & $1.5 \mathrm{a}$ & $1.5 \mathrm{~b}$ & $2.7 \mathrm{a}$ & $2.2 \mathrm{abc}$ & $3.6 \mathrm{abc}$ \\
\hline F. cerealis & 18 & $1.9 \mathrm{abc}$ & $1.1 \mathrm{a}$ & $1.2 \mathrm{~b}$ & $1.9 \mathrm{a}$ & $2.4 \mathrm{ab}$ & $4.4 \mathrm{a}$ \\
\hline F. solani & 14 & $2.2 \mathrm{ab}$ & $3.1 \mathrm{a}$ & $2.4 \mathrm{ab}$ & $2.9 \mathrm{a}$ & $2.3 \mathrm{abc}$ & $3.1 \mathrm{abcd}$ \\
\hline F. acuminatum & 11 & $1.1 \mathrm{bc}$ & $1.9 \mathrm{a}$ & $1.7 \mathrm{ab}$ & $1.3 \mathrm{a}$ & $2.4 \mathrm{ab}$ & $4.0 \mathrm{a}$ \\
\hline F. tricinctum & 4 & $1.5 \mathrm{abc}$ & $2.3 \mathrm{a}$ & $2.9 \mathrm{a}$ & $2.9 \mathrm{a}$ & $2.9 \mathrm{a}$ & $2.3 \mathrm{bcd}$ \\
\hline F. torulosum & 4 & $0.9 \mathrm{bc}$ & $0.6 \mathrm{a}$ & $1.6 \mathrm{ab}$ & $1.5 \mathrm{a}$ & $1.6 \mathrm{bc}$ & $3.6 \mathrm{abc}$ \\
\hline F. sporotrichioides & 2 & $0.8 \mathrm{c}$ & $0.9 \mathrm{a}$ & $2.6 \mathrm{ab}$ & $2.8 \mathrm{a}$ & $1.1 \mathrm{c}$ & $1.6 \mathrm{~d}$ \\
\hline F. graminearum & 1 & $0.4 \mathrm{c}$ & $0.9 \mathrm{a}$ & $1.7 \mathrm{ab}$ & $2.3 \mathrm{a}$ & $1.0 \mathrm{c}$ & $1.9 \mathrm{~cd}$ \\
\hline R-00738 z & 1 & $\ldots$ & $\ldots$ & $\ldots$ & $\ldots$ & $2.6 \mathrm{ab}$ & $3.0 \mathrm{abcd}$ \\
\hline
\end{tabular}

$\checkmark$ SGD and SDP methods $(14,21)$.

${ }^{w} \mathrm{EC}_{50}$ was compared with control plates without fungicides (14). All values are means of two experiments, with three replicate petri dishes per experiment. Numbers followed by the same letter within a column are not significantly different at $P=0.05$ by Tukey's honestly significantly difference test; ... indicates that data were not included for thiabendazole-insensitive $F$. sambucinum isolates or for isolates not from Michigan (R-00738, R. C Cetas) = a thiabendazole-sensitive standard isolate. These data are shown in Figure 3.

$\mathrm{x}$ Number of isolates.

${ }^{\text {y }}$ Mean $\mathrm{EC}_{50}$ values of 14 isolates of $F$. oxysporum or 6 isolates of $F$. sambucinum were sensitive to fludioxonil. The rest of the isolates of $F$. oxysporum ( $n=$ 54) and F. sambucinum $(n=25)$ were insensitive to fludioxonil with $\mathrm{EC}_{50}>100 \mathrm{mg} / \mathrm{liter}$ (Fig. 3).

${ }^{\mathrm{z}} \mathrm{R}-00738$ = thiabendazole-sensitive isolate of F. sambucinum (R-00738, R. C. Cetas). 
inoculated onto healthy tubers of Dark Red Norland that were stored either at 4 or $10^{\circ} \mathrm{C}$. This is in contrast to recent reports from the north-central United States, where $F$. graminearum has been reported to be the predominant dry rot pathogen on tubers stored at $10^{\circ} \mathrm{C}$, although less virulent than isolates of $F$. sambucinum (13). $F$. culmorum, although previously reported from potato tubers $(19,24,43)$, was not isolated in this study. This was the only species previously reported on potato in the United States that was not found on Michigan seed lots in this survey. The ability of isolates of all Fusarium spp. to cause dry rot at both 4 and $10^{\circ} \mathrm{C}$ storage temperatures indicated a potential for all of these species to infect both seed and chipping potato (9) but this should be investigated further.

Determination of baseline sensitivity levels of Fusarium isolates to new fungicides used for potato tuber seed treatments, and monitoring for sensitivity of the isolates measured, are important for management of dry rot pathogens (23). Monitoring studies help detect changes in sensitivity of pathogen isolates in the field (40) and become practically feasible when a relatively high frequency of fungicide-resistant isolates $(>1 \%)$ is reached, according to the Fungicide Resistance Action Committee (6). In vitro testing of the $\mathrm{EC}_{50}$ is a technique commonly used for monitoring shifts in sensitivity of pathogen populations to specific fungicides (40). Use of the SGD fungicide method for fungal pathogens to determine the $\mathrm{EC}_{50}$ has been used widely (14). In this Michigan seed lot study, the SGD method was compared with the traditional SDP method $(14,21)$ for determination of $\mathrm{EC}_{50}$ values. Although significant differences were measured in $\mathrm{EC}_{50}$ among isolates of the Fusarium spp. for all three fungicides tested using the SGD method but not the SDP method (for which only TBZ results showed significant differences in sensitivity among isolates), the results showed $\mathrm{EC}_{50}$ values of the same order of magnitude for both methods.

Fludioxonil is a protectant fungicide used effectively to reduce potato seed piece decay and sprout rot (50). In vitro insensitivity to fludioxonil has been reported for isolates of $F$. sambucinum, $F$. coeruleum (39), F. sambucinum, and F. oxysporum (16). In this study, $20 \%$ of $F$. oxysporum isolates and $9 \%$ of $F$. sambucinum isolates were insensitive to fludioxonil. All isolates of the other nine species recovered were sensitive to fludioxonil. The discovery of insensitive isolates may pose a challenge to controlling Fusarium seed piece decay in seed tuber production in Michigan. Although it is not known whether the isolates tested had previously been exposed to fludioxonil during bulking of certified seed for commercial use, it is important to maintain good management practices during tuber cutting and storage of cut seed (49) prior to planting. This study did not provide compelling evidence to suggest that fludioxonil seed treatments had failed because of insensitivity of Fusarium spp. to this fungicide. However, the presence of fludioxonil-insensitive strains necessitates the development and registration of fungicides with different modes of action for use on potato tubers. If possible, fungicides with alternative modes of action should be used more for seed potato production than for commercial potato production.

In this study, resistance to TBZ was found only in isolates of $F$. sambucinum. This is in contrast to other studies in which other Fusarium spp. insensitive to TBZ have been reported, including $F$. oxysporum, $F$. solani, and $F$. culmorum $(19,34) ; F$. avenaceum, $F$. equiseti, and F. sporotrichioides (34); F. acuminatum (19); and F. culmorum (20). It is not clear why previous studies have found TBZ resistance in other species and no such resistance was observed in this Michigan seed lot survey but this indicates that TBZ could still be used to control Fusarium dry rot in Michigan seed production as long as the causal agent is not $F$. sambucinum. Regular evaluation of Fusarium spp. composition in seed lot production in Michigan is necessary to justify continued use of TBZ. In addition, because no other fungicides have been registered for postharvest use against Fusarium dry rot on potato in Michigan, cultural practices should not be neglected.

Although in vitro sensitivities to fludioxonil (38) and TBZ $(19,37)$ have been reported previously for Fusarium spp. causing potato dry rot, this is the first study to present baseline sensitivity of difenoconazole. Difenoconazole is a systemic demethylation inhibitor fungicide that has been recommended by Adaskaveg and Förster (1) for registration against potato tuber rots caused by Fusarium spp. Other triazoles, including prothioconazole and tebuconazole, have been tested against Fusarium spp. on crops such as wheat, with $\mathrm{EC}_{50}$ values of 0.1 to 3.2 and 1.1 to $5.5 \mathrm{mg} / \mathrm{liter}$, respectively (29). All the isolates tested in this Michigan study came from tubers that had not previously been exposed to difenoconazole because this fungicide had not been used previously in seed potato tuber production in Michigan. All 228 Fusarium isolates were sensitive to difenoconazole. However, monitoring for changes in sensitivity to difenoconazole among isolates of Fusarium spp. that can cause tuber dry rot is important. Although this study indicated that difenoconazole was effective against Fusarium spp. isolated from potato tubers in Michigan, Allen et al. (3) reported that difenoconazole had a limited effect on growth of Fusarium spp. isolated from pine seed. Difenoconazole has an additional benefit in the potential for activity against other potato pathogens. For example, Olaya et al. (35) reported that difenoconazole was effective at reducing growth of Colletotrichum coccodes and, hence, could be used for control of black dot of potato.

\section{Acknowledgments}

This research was funded, in part, by the Michigan AgBioResearch GREEEN (Generating Research and Extension to meet Economic and Environmental Needs) Project GR 08/071, Michigan Potato Industry Commission, and supported in principal by the NCERA 211 (Quad State Potato Group), CSREES Hatch Project Number MICL01966, and the Michigan Potato Industry Commission.

\section{Literature Cited}

1. Adaskaveg, J. E., and Förster, H. 2010. New developments in postharvest fungicide registrations for edible horticultural crops and use strategies in the United States. Pages 107-117 in: Postharvest Pathology. D. Prusky and M. L. Gullino, eds. Springer, New York.

2. Ali, S., Rivera, V. V., and Secor, G. A. 2005. First report of Fusarium graminearum causing dry rot of potato in North Dakota. Plant Dis. 89:105.

3. Allen, T., Enebak, S., and Carey, W. 2004. Evaluation of fungicides for control of species of Fusarium on longleaf pine seed. Crop Prot. 23:979-982.

4. Aprasad, K., Bateman, G., and Read, P. 1997. Variation in pathogenicity on potato tubers and sensitivity to thiabendazole of the dry rot fungus Fusarium avenaceum. Potato Res. 40:357-365.

5. Boyd, A. E. W. 1972. Potato storage diseases. Rev. Plant Pathol. 51:297321.

6. Brent, K. J., and Hollomon, D. W. 2007. Fungicide resistance: the assessment of risk. Pages 17-21 in: FRAC Monograph No. 1, Second ed. Fungicide Resistant Action Committee, Brussels.

7. Choiseul, J., Allen, L., and Carnegie, S. 2006. Fungi causing dry tuber rots of seed potatoes in storage in Scotland. Potato Res. 49:241-253.

8. Cullen, D. W., Toth, I. K., Pitkin, Y., Boonham, N., Walsh, K., Barker, I., and Lees, A. K. 2005. Use of quantitative molecular diagnostic assays to investigate Fusarium dry rot in potato stocks and soil. Phytopathology 95:1462-1471.

9. Daami-Remadi, M., Jabnoun-Khiareddine, H., Ayed, F., and El-Mahjoub, M. 2006. Effect of temperature on aggressivity of Tunisian Fusarium species causing potato (Solanum tuberosum L.) tuber dry rot. Agron. J. 5:350355.

10. Desjardins, A., Christ-Harned, E., McCormick, S., and Secor, G. 1993. Population structure and genetic analysis of field resistance to thiabendazole in Gibberella pulicaris from potato tubers. Phytopathology 83:164-170.

11. Desjardins, A. E. 1995. Population structure of Gibberella pulicaris (anamorph Fusarium sambucinum) from potato tuber dry rot in North America and Europe. Am. Potato J. 72:145-156.

12. Desjardins, A. E. 2006. Fusarium Mycotoxins, Chemistry, Genetics, and Biology. American Phytopathological Society, St. Paul, MN.

13. Estrada, R., Jr., Gudmestad, N. C., Rivera, V. V., and Secor, G. A. 2010. Fusarium graminearum as a dry rot pathogen of potato in the USA: prevalence, comparison of host isolate aggressiveness and factors affecting etiology. Plant Pathol. 59:1114-1120.

14. Förster, H., Kanetis, L., and Adaskaveg, J. 2004. Spiral gradient dilution, a rapid method for determining growth responses and 50\% effective concentration values in fungus-fungicide interactions. Phytopathology 94:163170.

15. Gachango, E., Kirk, W., Hanson, L., Rojas, A., and Tumbalam, P. 2011. First report of Fusarium torulosum causing dry rot of seed potato tubers in the United States. Plant Dis. 95:1194. 
16. Gachango, E., Kirk, W., Hanson, L., Rojas, A., Tumbalam, P., and Shetty, K. 2011. First report of in vitro fludioxonil-resistant isolates of Fusarium spp. causing potato dry rot in Michigan. Plant Dis. 95:228.

17. Geiser, D., del Mar Jiménez-Gasco, M., Kang, S., Makalowska, I., Veeraraghavan, N., Ward, T., Zhang, N., Kuldau, G., and O'Donnell, K. 2004. Fusarium-ID v. 1.0: a DNA sequence database for identifying Fusarium. Eur. J. Plant Pathol. 110:473-479.

18. Goodwin, S., and Drenth, A. 1997. Origin of the A2 mating type of Phytophthora infestans outside Mexico. Phytopathology 87:992-999.

19. Hanson, L., Schwager, S., and Loria, R. 1996. Sensitivity to thiabendazole in Fusarium species associated with dry rot of potato. Phytopathology 86:378-384.

20. Hide, G. A., Read, P. J., and Hall, S. M. 1992. Resistance to thiabendazole in Fusarium species isolated from potato tubers affected by dry rot. Plant Pathol. 41:745-748.

21. Kanetis, L., Förster, H., and Adaskaveg, J. E. 2008. Baseline sensitivities for new postharvest fungicides against Penicillium spp. on citrus and multiple resistance evaluations in $P$. digitatum. Plant Dis. 92:301-310.

22. Kirk, W. W., and Wharton, P. 2008. Fusarium dry rot posing problems in potatoes. In: Vegetable Crop Advisory Team Alert Michigan Potato Diseases, Michigan State University. http://tinyurl.com/3jzmx41

23. Kuck, K. H., and Gisi, U. 2008. FRAC mode of action classification and resistance risk of fungicides. Pages 415-432 in: Modern Crop Protection Compounds. W. Krämer and U. Schirmer, eds. Wiley-VCH Verlag GmbH, Weinheim, Germany.

24. Kwasna, H., and Chelkowski, J. 1989. Occurrence of Fusarium crookwellense in Poland. Acta Mycol. 24:173-177.

25. Lacy, M. L., and Hammerschmidt, R. 1993. Fusarium dry rot. Mich. State Univ. Ext. Bull. E-2448, East Lansing, MI.

26. Leach, S., and Webb, R. 1981. Resistance of selected potato cultivars and clones to Fusarium dry rot. Phytopathology 71:623-629.

27. Leslie, J., Summerell, B., and Bullock, S. 2006. The Fusarium Laboratory Manual. Wiley-Blackwell, Ames, IA.

28. Mahdavi-Amiri, M., M. Razavi, K. S., and Zare, R. 2009. Investigation on genetic diversity of Fusarium oxysporum causing potato Fusarium wilt by pathogenicity tests and RAPD markers. Iran J. Plant Pathol. 45:1.

29. Michigan Potato Industry Commision. 2012. http://www.mipotato.com/ CMDocs/MPIC/Potato\%20Book_Layout\%201.pdf

30. Müllenborn, C., Steiner, U., Ludwig, M., and Oerke, E. C. 2008. Effect of fungicides on the complex of Fusarium species and saprophytic fungi colonizing wheat kernels. Eur. J. Plant Pathol. 120:157-166.

31. Niemira, B. A., Kirk, W. W., and Stein, J. M. 1999. Screening for late blight susceptibility in potato tubers by digital analysis of cut tuber surfaces. Plant Dis. 83:469-473.

32. Nirenberg, H. I. 1995. Morphological differentiation of Fusarium sambucinum Fuckel sensu stricto, $F$. torulosum (Berk. \& Curt.) Nirenberg comb. nov. and F. venenatum Nirenberg sp. nov. Mycopathologia 129:131-141.

33. Nolte, P., Bertram, M., Bateman, M., and McIntosh, C. 2003. Comparative effects of cut and treated seed tubers vs. untreated whole seed tubers on seed decay, Rhizoctonia stem canker, growth, and yield of Russet Burbank potatoes. Am. J. Potato Res. 80:1-8.

34. Ocamb, C., Hamm, P., and Johnson, D. 2007. Benzimidazole resistance of
Fusarium species recovered from potatoes with dry rot from storages located in the Columbia Basin of Oregon and Washington. Am. J. Potato Res. 84:169-177.

35. Olaya, G., Cochran, A., and Neil, G. 2010. Difenoconazole baseline sensitivity distribution of Colletotrichum coccodes isolates from potatoes. (Abstr.) Phytopathology 100:S93.

36. O'Neal, M. E., Landis, D. A., and Isaacs, R. 2002. An inexpensive, accurate method for measuring leaf area and defoliation through digital image analysis. J. Econ. Entomol. 95:1190-1194.

37. Peters, J. C., Lees, A. K., Cullen, D. W., Sullivan, L., Stroud, G. P., and Cunnington, A. C. 2008. Characterization of Fusarium spp. responsible for causing dry rot of potato in Great Britain. Plant Pathol. 57:262-271.

38. Peters, R. D., Platt, H. W., Drake, K. A., Coffin, R. H., Moorehead, S. Clark, M. M., Al-Mughrabi, K. I., and Howard, R. J. 2008. First report of fludioxonil-resistant isolates of Fusarium spp. causing potato seed-piece decay. Plant Dis. 92:172.

39. Powelson, M. L., and Rowe, H. C. 2008. Managing diseases caused by seedborne and soilborne fungi and fungus-like pathogens. Pages 183-195 in: Potato Health Management. D. A. Johnson, ed. American Phytopathological Society, St. Paul, MN.

40. Russell, P. 2003. Sensitivity baselines in fungicide resistance research and management. Page 10 in: FRAC Monogr. No. 3. Fungicide Resistance Action Committee, Brussels.

41. Secor, G. A., and Johnson, S. B. 2008. Seed tuber health before and during planting. Pages 43-54 in: Potato Health Management. D. A. Johnson, ed. American Phytopathological Society, St. Paul, MN.

42. Secor, G. A., and Salas, B. 2001. Fusarium dry rot and Fusarium wilt. Pages 23-25 in: Compendium of Potato Diseases. W. R. Stevenson., R. Loria., G. D. Franc, and D. P. Weingartner, eds. American Phytopathological Society, St. Paul, MN.

43. Seppanen, E. 1981. Fusariums of the potato in Finland, III. Varietal resistance of potato tubers to some Fusarium species. Ann. Agric. Fenn. 20:177-183.

44. Singh, B., Nagaich, B., and Saxena, S. 1987. Fungi associated with dry rot of potatoes, their frequency and distribution. Indian J. Plant Pathol. 5:142-145.

45. Theron, D., and Holz, G. 1989. Fusarium species associated with dry and stem-end rot of potatoes in South Africa. Phytophylactica 21:175-181.

46. Venter, S. L., Theron, D., Steyn, P., Ferreira, D., and Eicker, A. 1992. Relationship between vegetative compatibility and pathogenicity of isolates of Fusarium oxysporum f. sp. tuberosi from potato. Phytopathology 82:858862.

47. Wang, P. J., and Hu, C. Y. 1985. Potato tissue culture and it applications in agriculture. Pages 503-577 in: Potato Physiology. P. H. Li, ed. Academic Press, Inc., London.

48. Wharton, P., Hammerschmidt, R., and Kirk, W. 2007. Fusarium dry rot Mich. State Univ. Ext. Bull. E-2995, East Lansing, MI

49. Wharton, P., Kirk, W., Berry, D., and Tumbalam, P. 2007. Seed treatment application-timing options for control of Fusarium decay and sprout rot of cut seedpieces. Am. J. Potato Res. 84:237-244.

50. Wharton, P. S., Tumbalam, P., and Kirk, W. W. 2006. First report of potato tuber sprout rot caused by Fusarium sambucinum in Michigan. Plant Dis. 90:1460. 